Ann. Biol. anim. Bioch. Biophys., 1978, 18 (5), 1229-1235.

\title{
Plasma prolactin variations and cyclic ovarian activity in ewes submitted to different light regimens
}

\author{
par J. THIMONIER, J. P. RAVAULT ${ }^{(1)}$, R. ORTAVANT \\ with the technical assistance of N. POULAIN and A. BEGUEY \\ Station de Physiologie de la Reproduction, I.N.R.A., \\ Nouzilly, 37380 Monnaie, France.
}

\begin{abstract}
Summary. In the lle-de-France ewe, the secretion of prolactin comes under important seasonal variations. The highest levels are in summer $(200 \mathrm{ng} / \mathrm{ml})$ and the lowest in winter $(10 \mathrm{ng} / \mathrm{ml})$. Using the hypothesis of Bunning, we studied a photoinducible phase during diurnal cycle and the influence on ovarian activity. Ewes preconditioned in long photoperiods were subjected for 15 months to normal variations of daylength or to $8 \mathrm{hrs}$ of illumination in two fractions of 7 and 1-hr duration. The beginning of the 7-hour peroid was considered to be a subjective dawn, and the 1-hr light pulse was given at various times after dawn : at hours 11, 14, 17 and 20. For light pulse at hour 17, the first 2 months following beginning of light treatment were characterized by an increase in prolactin, but a seasonal variation in prolactin levels was noted in all groups with different amplifude of variation. Light treatment did not modify onset of ovarian cyclicity the first year in the treated groups, but the end occurred earlier than for the controls. The second period of ovarian activity was characterized by abnormal duration.
\end{abstract}

Prolactin secretion is sensitive to variation in light or temperature. Thus, in the bovine (Schams and Reinhardt, 1974 ; Lacroix ef al., 1977) ; caprine (Buttle, 1974 ; Hart, 1975), ovine (Pelletier, 1973 ; Ravault, 1976) maximum levels are observed in the summer, that is during the longest days with high temperature. Lowest levels are observed during the shortest days with low temperature. Furthermore, duration of artificial light only affects the pattern of secretion since Pelletier (1973) reported that prolactin levels are highest with $16 \mathrm{hrs}$ of light and lowest with $8 \mathrm{hrs}$. The temperature was held constant $\left(18^{\circ} \mathrm{C}\right)$. It has also been demonstrated that a period of photosensitivity for prolactin exists during the diurnal cycle and this photosensitive phase is situated about 16 hrs after dawn (Ravault and Ortavant, 1977) in the ram.

Several questions come to mind :

- Does light affect prolactin secretion in the ewe as observed in the ram?

- Is it possible to show a photosensitive period for prolactin in the ewe?

- What are the relationships between prolactin and resumption of seasonal variation of ovarian activity?

These were the objectives of the present experiment.

(1) Reprint requests to: J. P. Ravault. 


\section{Material and methods.}

Forty eight lle-de-France ewes, 1.5 to 2 years old at the beginning of the experiment, were divided into 6 groups of 8 females each, during the month of April. Age, weight and type of birth (single or twins) were considered in assignment of ewes to groups.

During a 2-month preexperimental period, ewes were subjected to normal variations of daylength. Control of artificial light in the pens (300 lux) or darkness were obtained with programmed clocks. Modifications of daylength were made each week.

To study the influence of light on prolactin secretion, we used the hypothesis of Bunning (1960) with skeleton light treatment.

Beginning on the 23rd June ( $16 \mathrm{hrs}$ of light) females, now adapted to a long daylength period, were subjected for 15 months either to normal variations of daylength (G 1 : controls), or to $8 \mathrm{hrs}$ of light daily. The light was given either in 1 (G 2) or 2 fractions (G 3, G 4, G 5, G 6) of 7 and one $1 \mathrm{hr}$ duration ; beginning of the $7 \mathrm{hr}$ period $(5.30 \mathrm{a}$. m.) was considered to be a subjective dawn. The light pulse of $1 \mathrm{hr}$ was given at various times after dawn, that is at hour 11 (G 3), 14 (G 4), 17 (G 5) or 20 (G 6) (fig. 1) as previously described by Ravault and Ortavant (1977) and Ortavant (1977).
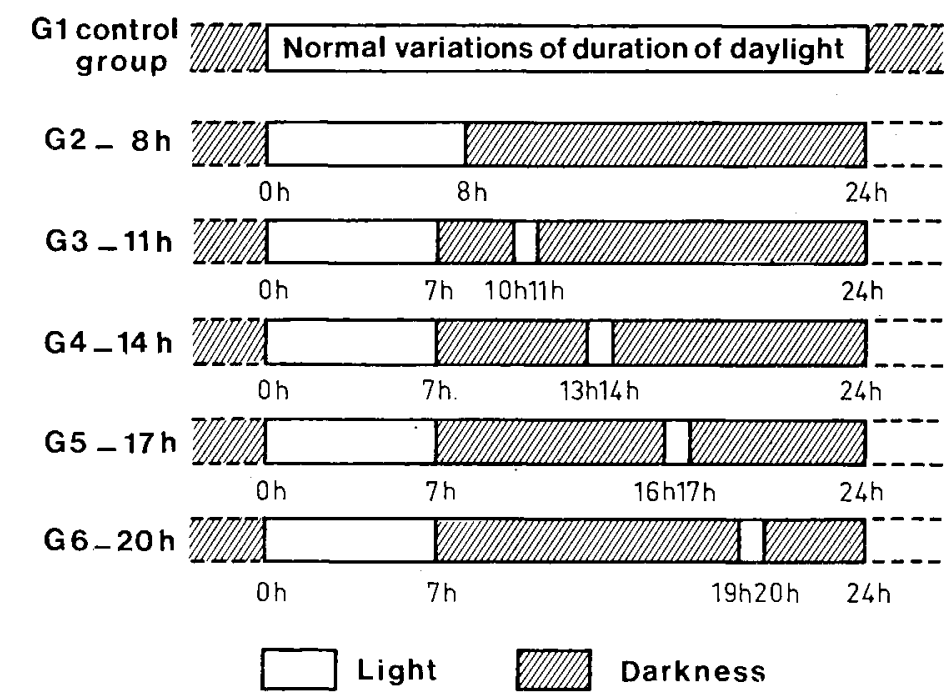

FIG. 1. - Experimental protocol. The beginning of the 7-hour period is $5.30 \mathrm{a} . \mathrm{m}$.

The females received a constant level of feeding (pellets of maize and lucerne plus straw) during the whole experimental period. Ewes were not sheared during the observation period. The temperature varied according to the season.

Ewes were bled twice weekly from the jugular vein. Blood collections were done at $11 \mathrm{a}$. $\mathrm{m}$. during the $7 \mathrm{hrs}$ of light, always at the same time relative to dawn except for the controls (G 1). For the control females, the interval from dawn to bleeding varied during the experimental period. 
After centrifugation, plasma was frozen and stored at $-20^{\circ} \mathrm{C}$ until assay. Progesterone assays were done with a technique similar to that described by Terqui and Thimonier (1974). Prolactin was assayed with the method described by Kann (1971). It was possible from progesterone analysis to define the periods of cyclic ovarian activity (œstrus was not detected) and periods of deep anoestrus for all females (Thimonier, 1977 unpublished). For prolactin, the mean monthly concentrations for each group were calculated. The means of the concentrations of all samples of all females of a given group for a month were calculated without considering if females were cycling or the period of the estrous cycle. Variations of the mean monthly concentrations were expressed as a percentage of the concentration of the preexperimental period (June only).

\section{Results.}

A. - Cycle ovarian activity (Table 1). - The onset of ovarian cyclicity for the controls, based on progesterone determinations, were the 5th and the 28th of August for the first and the second year, respectively. The end of ovarian cyclicity occurred at the beginning of February. Light treatments did not modify onset of ovarian cyclicity the first year in the treated groups (beginning of August). But whatever the light pulse treatment, the end of the first period of ovarian activity occurred earlier than for the controls (mid-November versus beginning of February).

TABLE 1

Ovarian activity in light-treated ewes

\begin{tabular}{lccccc}
\hline Groups & $\begin{array}{c}\text { Onset of 1st } \\
\text { period } \\
\text { (date) }\end{array}$ & $\begin{array}{c}\text { Duration } \\
\text { (days) }\end{array}$ & $\begin{array}{c}\text { End of 1st } \\
\text { period } \\
\text { (date) }\end{array}$ & $\begin{array}{c}\text { Duration of } \\
\text { ovarian inactivity } \\
\text { (days) }\end{array}$ & $\begin{array}{c}\text { Onset of 2nd } \\
\text { period } \\
\text { (dafe) }\end{array}$ \\
\hline G 1 controls. & $5-8 \pm 6.7$ & $182 \pm 11.0$ & $3-2 \pm 5.3$ & $207 \pm 5.9$ & $28-8 \pm 5.0$ \\
G 2 8 hrs $\ldots$. & $4-8 \pm 2.6$ & $99 \pm 5.7$ & $11-11 \pm 6.5$ & $206 \pm 7.1$ & $4-6 \pm 10.1$ \\
G 3 $10-11 \ldots$ & $2-8 \pm 3.1$ & $93 \pm 5.6$ & $2-11 \pm 4.6$ & $161 \pm 6.9$ & $12-4 \pm 7.7^{*}$ \\
G 4 $13-14 \ldots$ & $30-7 \pm 3.6$ & $118 \pm 10.6$ & $24-11 \pm 10.7$ & $168 \pm 12.6$ & $12-5 \pm 8.7$ \\
G 5 $16-17 \ldots \ldots$ & $12-8 \pm 7.8$ & $107 \pm 15.4$ & $29-11 \pm 9.7$ & $158 \pm 12.9$ & $6-5 \pm 12.2$ \\
G 6 $19-20 \ldots$ & $5-8 \pm 2.1$ & $102 \pm 7.5$ & $15-11 \pm 6.5$ & $165 \pm 12.0$ & $28-4 \pm 9.8$ \\
\hline
\end{tabular}

* One female without ovarian activity.

Onset of the second period of ovarian activity was also earlier $(P<0.05)$ for all the light-treated females (G 2, G 3, G 4, G 5, G 6). However, for all the light-treated groups, this second period of ovarian activity was characterized by abnormal duration and irregular succession of cycles.

The duration of deep anoestrus was also significantly shorter for groups $G 3, G 4$, $G 5$ and $G 6$ than for group $G 1$ and $G 2$.

B. - Prolactin (fig. 2 and 3). - For controls, mean monthly plasma concentrations followed a seasonal variation which parallels that of daylentgh. The maximum 
level was observed in June and/or July at a time of the longest daylight, and the minimum was coincident with that of shortest daylight in December (fig. 2).

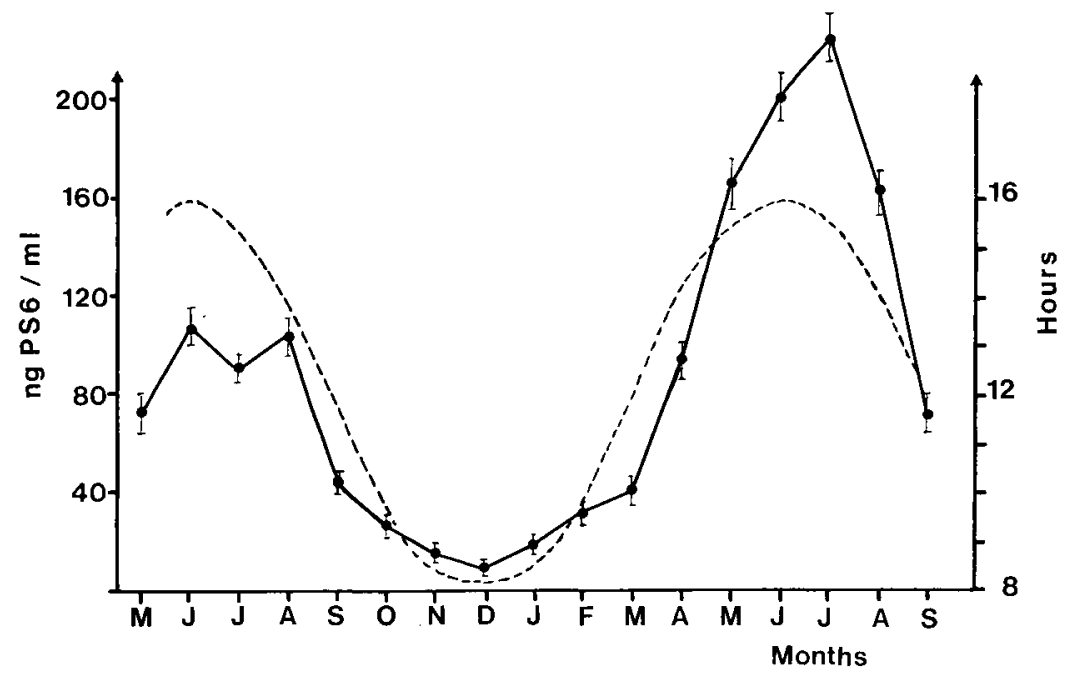

FIG. 2. - Seasonal variations of prolactin levels in control groups (7 ewes bled twice weekly) - prolactin ; - . - - daylight.

Highest concentrations were noted at the same period for each year, but they were at least twice higher the second year.

For females receiving a light pulse from 16 to 17 hrs after dawn (G 5), prolactin concentrations expressed as a percentage of the preexperimental level for that group were always higher than those measured in the other treated groups throughout the year. For $\mathrm{G} 5$ (pulse at $17 \mathrm{~h}$ ) the first 2 months following beginning of light treatment were characterized by an increase in prolactin (fig. 3). For all other groups, a decrease was defected.

Although constant photoperiods were maintained for 15 months, a seasonal variation in prolactin levels was noted for all groups. The highest and lowest levels appeared at the same period for all treatment groups coincident with those for controls. But amplitude of variations were different among groups and it was possible to classify the light-treated groups. Amplitudes of variations were smallest for Group 2, increased progressively for G 3, G 4 and G 5 and decreased for Group 6 (fig. 3).

\section{Discussion and conclusion.}

A seasonal variation of prolactin secretion is thus demonstrated for ewes submitted to normal variations in daily photoperiod as has been reported for the ram (Pelletier, 1973 ; Ravault, 1976 ; Ravault and Ortavant, 1977) goat (Buttle, 1974 ; Hart, 1975) and cow (Thatcher, 1974 ; Schams and Reinhardt, 1974). The increase in prolactin concentration from the first to the second year has also been reported for the ram (Ravault, 


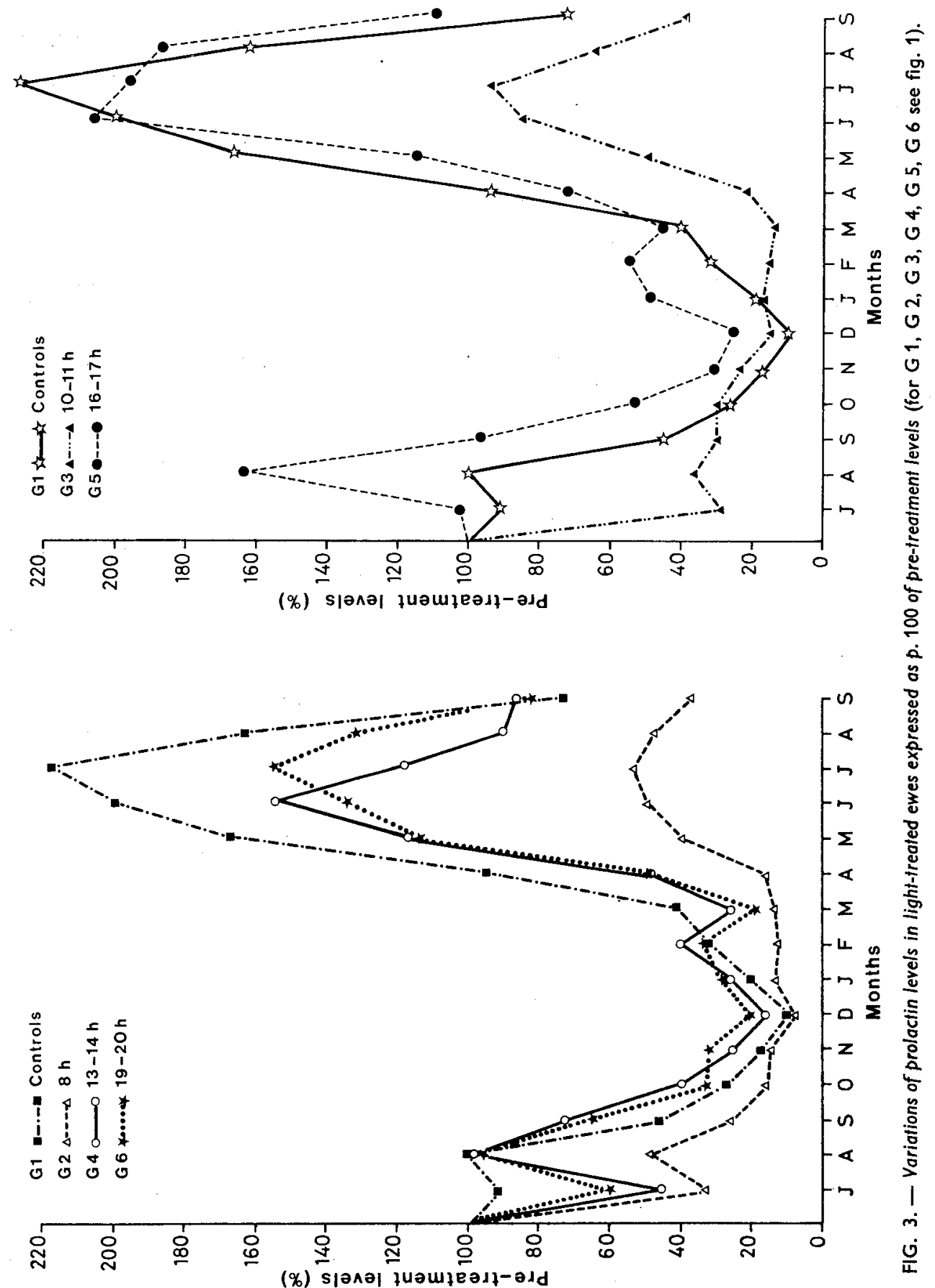


1976) and may be due to an effect of age. This age effect may account for the year difference detected for the ewe in the present experiment.

As for the ram (Ravault and Ortavant, 1977 ; Ortavant, 1977), we have shown a photosensitive phase, during the diurnal cycle, for prolactin in the female. The period of photosensitivity is between hours 15 and 19 after dawn. The light pulse given during hour 17 after dawn caused higher peripheral prolactin concentrations than those observed for light pulses given during hour 14 or 20 . However, maintenance of this light pulse is unable to sustain constant high levels of prolactin. This fact can be explained either by displacement of the photosensitive period during the diurnal cycle or by a « fatigue » phenomenon described in the ram (Ravault and Ortavant, 1977).

Existence of seasonal variations of plasma prolactin for all females of the groups receiving a constant duration of light for 15 months is interesting. It may be due to an endogenous rhythm starting during fetal life, or first years of life, or to seasonal variations of temperature. Temperature was not controlled in the light pulse treatment. Variations of temperature have already been shown to affect prolactin secretion in the bovine (Tucker and Weteman, 1976). However, Alberio and Ravault (unpublished) have indicated that temperature was nearly ineffective in altering secretion in the ram. This point however has not been complefely elucidated until now in the ewe.

Onset of the period of cyclic ovarian activity is observed when daylength is decreasing after a period of high prolactin concentrations. The end of ovarian cycles appears when daylight is increasing after a period of low prolactin concentrations. Under our experimental conditions, duration of the period of ovarian cyclicity was comparable to the length of the normal season of reproduction for females of the lle-de-France breed (Thimonier and Mauléon, 1969).

For all groups receiving 8 hours of light in either 1 or 2 parts, onset of the first period of ovarian activity was not modified compared to controls. Processes leading to the onset of ovarian activity were already in progress at the end of June. However, end of ovarian cyclicity was earlier for all light-treated groups. The second period of ovarian activity started when prolactin was increasing for the treatment groups, which is contrary to that observed for controls. In lle-de-France ewes, prolactin does not appear to have an inhibitory effect on resumption of ovarian activity from seasonal anoestrus and is therefore different in its possible inhibitory role during the postpartum period (Kann and Martinet, 1975). Relationships between prolactin and sexual activity in the ewe warrant further study.

Reçu en mars 1978.

Accepté en mai 1978.

Aknowledgments. - We thank Dr. W. W. Thatcher for the translation of the manuscript, NIH for providing ovine prolactin. This work was supported by an ATP-CNRS no 1832 (Physiological Ecology).

Résumé. Chez la brebis lle-de-France, la prolactine présente les taux les plus élevés en été $(200 \mathrm{ng})$ et les plus bas en hiver $(10 \mathrm{ng})$.

En utilisant l'hypothèse de Bunning, nous avons recherché une phase photosensible au cours du rythme diurne et l'influence sur l'activité ovarienne. Des brebis, préconditionnées en jours longs, sont soumises pendan 15 mois soif aux variations normales de la durée du jour, soit à $8 \mathrm{~h}$ d'éclairement en deux fractions d'une durée de $7 \mathrm{~h}$ et de $1 \mathrm{~h}$. Le début de 
la photopériode de $7 \mathrm{~h}$ était considérée comme aube subjective et l'impulsion lumineuse était donnée à différents moments après l'aube, c'est-à-dire à la $11 \mathrm{e}, 14^{\mathrm{e}}, 17^{\mathrm{e}}$ et $20^{\mathrm{e}}$ heure.

Pour l'impulsion lumineuse à $17 \mathrm{~h}$ après l'aube, les deux premiers mois suivant le début du traifement lumineux étaient caractérisés par une augmentation du taux de prolactine ; mais une variation saisonnière dans le taux de cette hormone était observée chez tous les groupes avec des amplitudes différentes de variation.

Les traitements lumineux ne modifient pas le début de l'activité ovarienne la première année. Mais la fin de saison arrive plus tôt que chez les contrôles. La seconde période d'activité ovarienne est caractérisée par une durée anormale.

\section{References}

BUNNING E., 1960. Circadian rhythms and time-measurement in photoperiodism. In Biological clocks. Cold spring Harb. Symp. Quant. Biol., 25, 249-257.

BUTTLE H. L., 1974. Seasonal variation of prolactin in plasma of male goats. J. Reprod. Fert., 37, 95-99.

HART I. C., 1975. Seasonal factors affecting the release of prolactin in goats in response to milking. J. Endocr., 64, 313-322.

KANN G., 1971. Dosage radioimmunologique de la prolactine plasmatique chez les ovins. C. R. Acad. Sci. Paris, Série D, 272, 2808-2811.

KANN G., MARTINET J., 1975. Prolactin levels and duration of postpartum anoestrus in lactating ewes. Nature, 257, 63-64.

LACROIX A., RAVAULT J. P., PELLETIER J., 1977. Plasma prolactin variations in the male calf in relation to age, season and breed. Ann. Biol. anim. Bioch. Biophys., 17, 1095-1099.

ORTAVANT R., 1977. Photoperiodic regulation of reproduction in the sheep, 58-71. In Proc. Symp. Management of reproduction in sheep and goats. Univ. Wisconsin, Madison, July 24-25.

PELLETIER J., 1973. Evidence for photoperiodic control of prolactin release in rams. J. Reprod. Fert., 35, 143-147.

RAVAULT J.P., 1976. Prolactin in the ram : seasonal variations in the concentration of blood plasma from birth until three years old. Acta endocrinol., 83, 720-725.

RAVAULT J. P., ORTAVANT R., 1977. Light control of prolactin secretion in sheep. Evidence for a photoinducible phase during a diurnal rhythm. Ann. Biol, anim. Bioch. Biophys., 17, 459-473.

SCHAMS D., REINHARDT V., 1974. Influence of the season on plasma prolactin level in cattle from birth to maturity. Horm. Res., 5, 217-226.

TERQUI M., THIMONIER J., 1974. Nouvelle méthode radioimmunologique rapide pour l'estimation du niveau de progestérone plasmatique. Application pour le diagnostic précoce de la gestation chez la brebis et la chèvre. C. R. Acad. Sci. Paris, Série D, 279, 1109-1112.

THATCHER W. W., 1974. Effects of season, climate and temperature on reproduction and lactation. J. Dairy Sci., 57, 360-368.

THIMONIER J., MAULEON P., 1969. Variations saisonnières du comportement d'œstrus ef des activités ovarienne et hypophysaire chez les ovins. Ann. Biol. anim. Bioch. Biophys., 9, 233-250.

TUCKER H. A., WETTEMAN R. P., 1976. Effects of ambient temperature and relative humidity on serum prolactin and growth hormone in heifers. Proc. Soc. Biol. Med., 151, 623-628. 